\title{
Distribution of the Mosquito Communities (Diptera: Culicidae) in Oviposition Traps Introduced into the Atlantic Forest in the State of Rio de Janeiro, Brazil
}

\author{
Shayenne Olsson Freitas Silva, ${ }^{1,2}$ Cecilia Ferreira de Mello, ${ }^{1,3}$ Ronaldo Figueiró,-6 \\ Daniele de Aguiar Maia, ${ }^{1,3}$ and Jeronimo Alencar $^{1}$
}

\begin{abstract}
The Atlantic Rainforest of South America is one of the major biodiversity hotspots of the world and serves as a place of residence for a wide variety of Culicidae species. Mosquito studies in the natural environment are of considerable importance because of their role in transmitting pathogens to both humans and other vertebrates. Community diversity can have significant effects on the risk of their disease transmission. The objective of this study was to understand the distribution of mosquito communities using oviposition traps in a region of the Atlantic Forest. Sampling was carried out in Bom Retiro Private Natural Reserve (RPPNBR), located in Casimiro de Abreu, Rio de Janeiro, using oviposition traps, which were set in the forest environment, from October 2015 to December 2016. The canonical correspondence analysis was used to assess the influence of the climatic variables (precipitation, maximum dew point, and direction) throughout the seasons on the population density of the mosquito species. The results showed that population density was directly influenced by climatic variables, which acted as a limiting factor for the mosquito species studied. The climatic variables that were significantly correlated with the density of the mosquito species were precipitation, maximum dew point, and direction. Haemagogus janthinomys was positively correlated with the three climatic variables, whereas Haemagogus leucocelaenus was positively correlated with precipitation and maximum dew point, and negatively correlated with direction.
\end{abstract}

Keywords: Aedes albopictus, climatic variables, Culicidae, eggs, Haemagogus janthinomys, Haemagogus leucocelaenus

\section{Introduction}

T he ATlantic Forest comprises a set of forest formations that have a rich diversity of mosquito species with considerable spatial variability. The topographic complexity of this environment allows the existence of a broad spectrum of microclimates and environmental conditions that influence the availability and sustainability of mosquito habitats (Alencar et al. 2011, Marques et al. 2012, Correa et al. 2014).

Climate change can affect biodiversity at different levels by accelerating the metabolism of some individuals, and affecting the food chains and ecological interactions of popu- lations and communities (Hughes 2000). One of the most critical issues related to climate change is its impact on disease vectors (Chaves and Koenraadt 2010). According to Alencar et al. (2011), the activity level of different mosquito species is directly influenced by the climatic variables, such as temperature and air humidity. Understanding their biodiversity, richness, abundance, and response to anthropological activities is essential for predicting changes in their populations (Alencar et al. 2016).

Community diversity can significantly increase the risk of pathogen transmission from vectors to humans (Keesing et al. 2006). Nevertheless, a greater variety of hosts in a more

\footnotetext{
${ }^{1}$ Diptera Laboratory, Oswaldo Cruz Institute (Fiocruz), Rio de Janeiro, Brazil.

${ }^{2}$ Postgraduate Program in Tropical Medicine, Oswaldo Cruz Institute (Fiocruz), Rio de Janeiro, Brazil.

${ }^{3}$ Postgraduate Program in Animal Biology, Institute of Biology, Federal Rural University of Rio de Janeiro, Rio de Janeiro, Brazil.

${ }^{4}$ Environmental Biotechnology Laboratory, Fundação Centro Universitário Estadual da Zona Oeste (UEZO), Rio de Janeiro, Brazil.

${ }^{5}$ Centro Universitário de Volta Redonda (UniFOA), Volta Redonda, Brazil.

${ }^{6}$ Universidade Castelo Branco (UCB), Rio de Janeiro, Brazil.
}

(C) Shayenne Olsson Freitas Silva et al. 2018; Published by Mary Ann Liebert, Inc. This Open Access article is distributed under the terms of the Creative Commons License (http://creativecommons.org/licenses/by/4.0), which permits unrestricted use, distribution, and reproduction in any medium, provided the original work is properly cited. 
diverse community with less competent hosts may reduce the incidence of the disease in the focal host by a "dilution effect." This hypothesis was demonstrated by Johnson and Thieltges (2010) in his observational study on the transmission of Schistosoma mansoni Sambon, 1907, where he found that increasing the diversity of a community substantially reduces the transmission of the parasite. This connection between species diversity and disease transmission by vectors is based on zooprophylaxis, using animals that attract hematophagous insects away from humans.

However, it has been suggested that high diversity can increase the risk of transmission when there is a greater supply of alternative hosts. The amount and activity of the insect vectors increase and these hosts function as alternative sources of infection. Hence, it is important to know the vector community, and eventually their hosts, to perform an overall assessment of the transmission risk (Holt and Pickering 1985, Norman et al. 1999, Gilbert et al. 2001, Schmidt and Ostfeld 2001, Saul 2003, Dobson 2004).

One of the surveillance methods for these vectors includes the use of oviposition traps. It is a sensitive method for mosquito detection (Resende et al. 2013) taking into consideration the species that do oviposit in ovitraps, which can generate indices that aid in the early detection of new infestations (Gomes 1998), and is economically and operationally viable (Braga and Valle 2007). This trap assists in the determination of geographic dispersion, density, frequency, and seasonality (Juliano 1998, Glasser and Gomes 2000, Passos et al. 2003). Some characteristics observed in the adult insects are largely a product of their larval environment (Braks et al. 2004), which may affect their vectorial competence (ability to become infected), and consequently, their ability to transmit the pathogen (Hardy and Monath 1988). Oviposition traps have been successfully used to obtain the eggs of Haemagogus leucocelaenus Dyar and Shannon, 1924 (Medeiros 2009), Haemagogus equinus Theobald, 1903 (Chadee and Tikasingh 1990), and Haemagogus janthinomys Dyar, 1921 (Alencar et al. 2004).

Mosquitoes of the genus Haemagogus Williston, 1896, and Sabethes Robineau-Desvoidy, 1827, are the most epidemiologically important species involved in the transmission of wild-type yellow fever virus, thereby acting as biological vectors in the forest areas of the Americas (Arnell 1973). The Haemagogus species are wild, with diurnal habits, and are most active in the tree canopies, however, some of these species show a tendency of adaptation to human environments (Marcondes and Alencar 2010). According to the Ministry of Health data from December 2016 to May 31, 2017, there were 3240 reports of suspected cases of wild-type yellow fever, of which $519(16 \%)$ remained under investigation, 792 (24.5\%) were confirmed, and 1929 (59.5\%) discarded. About 79 cases were reported to the State Health Department, Rio de Janeiro, of which 27 were confirmed and 55 discarded from January to August 2017. Of the 27 confirmed cases, 8 had their origin point from the municipality of Casimiro de Abreu and one from Silva Jardim.

This study observed the distribution of effective or potential vector species of wild-type yellow fever virus that colonize the oviposition traps and analyzed the influence of climatic variables (precipitation, maximum dew point, and direction) on the vector distribution during different seasons of the year in an area of the Atlantic Forest with confirmed wild-type yellow fever cases.

\section{Materials and Methods}

\section{Ethics statement}

The permanent license for collecting, capturing, and transporting zoological material from the RPPNBR was granted by the Environment and Agriculture Secretariat (SISBIO) with number: 34911-1, dated June 14, 2012, across all the national territory.

\section{Area of study}

The RPPNBR, Casimiro de Abreu Municipality, Rio de Janeiro State, $\sim 140 \mathrm{~km}$ from Rio de Janeiro, has an area largely covered by the typical Atlantic Forest vegetation that persists for most of the year under the control of the Tropical Mass (MTA) originated from the Tropical Atlantic Antictone. The region experiences average annual temperatures ranging from 18 to $24^{\circ} \mathrm{C}$, due to the marked solar radiation of tropical latitudes, and strong relative humidity due to intense sea evaporation. Because of its own characteristics, the dominance of this air mass maintains the stability of the weather, although interference from the Polar Fronts or discontinuities, and Tropical Instability Lines (Schobbenhaus et al. 1995), which promote weather instability, might occur during the year. Such disturbed currents are largely responsible for the annual rainfall, particularly along with the contribution of summer rains that generate a predominantly tropical humid climate (Takizawa 1995). The area of the RPPNBR in the Sao Joao River Basin is located in the intertropical zone (low latitudes), with intense solar radiation and great influence of the Atlantic Ocean (Cunha 1995), producing a tropical wet climate. Geographical coordinates of the sampling sites were obtained using the Garmin GPS map 60 CS GPS. Maps were prepared in ArcView10 and edited in Adobe Photoshop CS5 and CorelDraw X5. The sampling sites were as follows: Sites in RPPNBR, state of Rio de Janeiro, Brazil; Site 1-RPPNBR entrance, the secondary forest under the direct influence of the river and waterfalls $\left(22^{\circ} 27^{\prime} 19.4^{\prime \prime} \mathrm{S}, 42^{\circ} 18^{\prime} 09.5^{\prime \prime} \mathrm{W}\right)$; Site 2 -located near the reserve management, an anthropogenic environment and composed of forests in the advanced stage of regeneration $\left(22^{\circ} 27^{\prime} 15.4^{\prime \prime} \mathrm{S}, 42^{\circ} 18^{\prime} 02.4^{\prime \prime} \mathrm{W}\right)$; Site $3-$ the entrance to the forest, with vegetation in the advanced stage of regeneration $\left(22^{\circ} 27^{\prime} 19.5^{\prime \prime} \mathrm{S}, 42^{\circ} 18^{\prime} 01.5^{\prime \prime} \mathrm{W}\right)$; Site $4 \mathrm{a}$ and $4 \mathrm{~b}$ - forest with original vegetation and some parts showing bamboo monoculture $\left(22^{\circ} 27^{\prime} 14.1^{\prime \prime} \mathrm{S}, 42^{\circ} 17^{\prime} 34.9^{\prime \prime} \mathrm{W}\right)$; Site 5 -contains large areas with forests similar to the original biocenotic structure $\left(22^{\circ} 26^{\prime} 58.7^{\prime \prime} \mathrm{S} \mathrm{42}{ }^{\circ} 17^{\prime} 11.6^{\prime \prime} \mathrm{W}\right)$ (Fig. 1).

Monitoring was performed using oviposition traps that consisted of a black pot, with a $1 \mathrm{~L}$ capacity without a lid, and four plywood pallets (Eucatex ${ }^{\circledR}$ plates), measuring $2.5 \times 14 \mathrm{~cm}$, and fixed vertically inside the trap by "CLIPS" (Alencar et al. 2016). Natural water and remains of leaves and animals found on the forest soil were added into the trap to generate an ecosystem similar to the natural one. The oviposition traps were installed on trees by using a fishing sinker (diameter $\sim 4 \mathrm{~cm}$ ) and secured using a nylon rope, and 24 ovitraps were set at two heights (ground level and 2.50 meters) in the forest and monitored through October 2015 to December 2016, weekly by replacing the panels with new ones; 12 ovitraps were set for each height. All the paddles were sequentially numbered and placed in a humid 


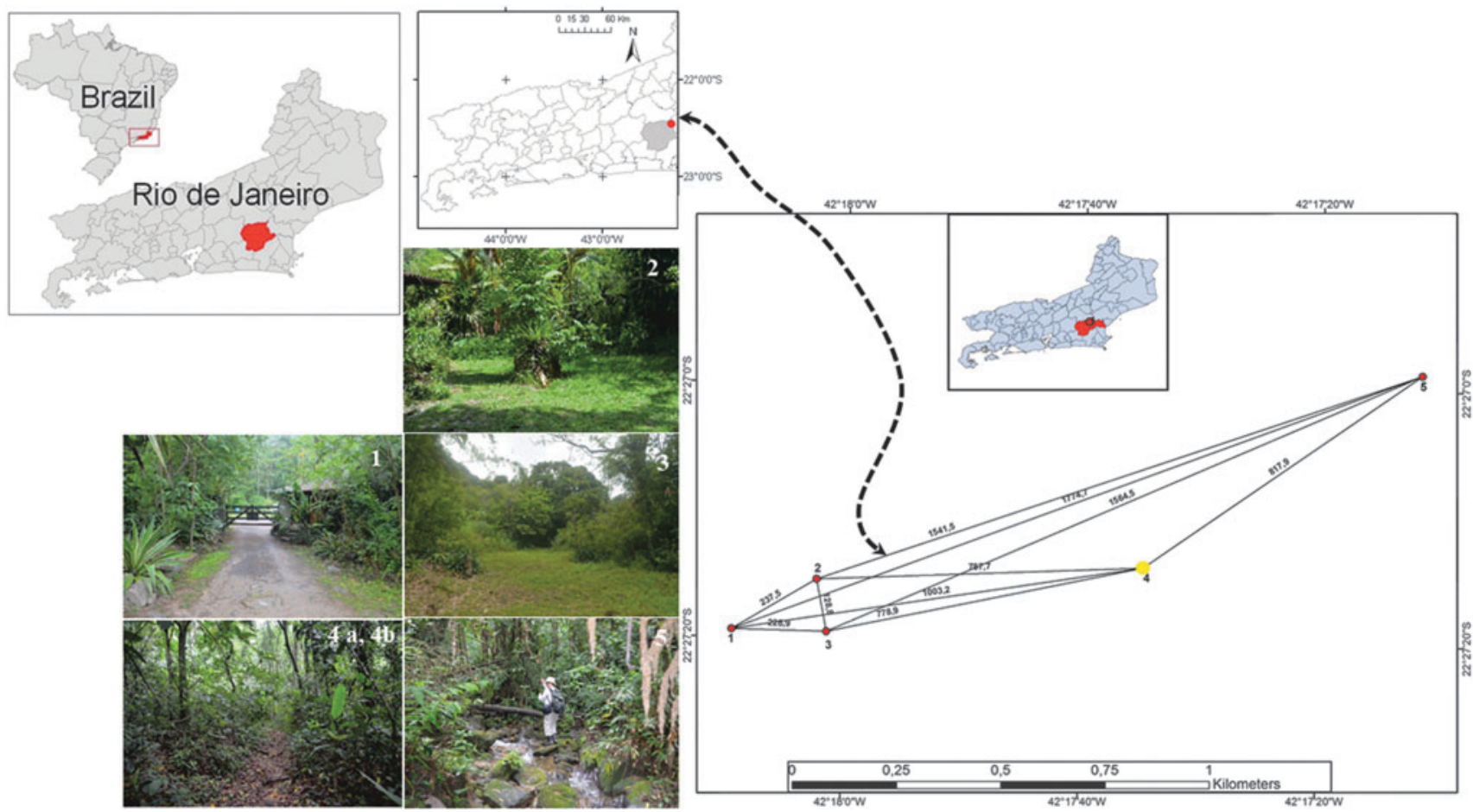

FIG. 1. Sampling sites in the RPPNBR, located in the city of Casimiro de Abreu, state of Rio de Janeiro. RPPNBR, Bom Retiro Private Natural Reserve.

chamber and sent to the Diptera Laboratory of the Oswaldo Cruz Institute.

In the laboratory, the positive paddles (containing eggs) were separated, had their eggs counted, and immersed in clear trays containing MiliQ ${ }^{\mathbb{R}}$ water. The collected eggs were placed to hatch in a controlled experimental environment, in a thermoperiod and a photoperiod regulated at $28^{\circ} \mathrm{C} \pm 1^{\circ} \mathrm{C}$, relative humidity of $75 \%$ to $90 \%$, and photoperiod of $10 \mathrm{~h}$. The specimens were kept alive for specific determination in adulthood, by direct observation of the morphological characters evidenced by the stereomicroscopic microscope (Zeiss ${ }^{\circledR}$ ) and consultation with the respective descriptions/ diagnoses of the spp, using dichotomous keys developed by Consoli and Oliveira (1994), Forattini (2002), and Marcondes and Alencar (2010). Abbreviations for the generic and subgeneric names were assigned in accordance to Reinert (2001). After species determination, all the specimens were incorporated into the Entomological Collection of the Oswaldo Cruz Institute, Fiocruz, under the title "Culicidae Mata Atlântica."

The data were analyzed to assess the ecological relationship between the Culicidae populations and the climatic variables of the study area. The Canoco 4.5 program was used to evaluate and compare the differences in the composition of the mosquito communities and the relationship between the population density and the climatic variables (precipitation, maximum dew point, and direction) (Ter Braak and Simaluaer 2002). The canonical correspondence analysis was performed to evaluate the correlation structure between the mosquito community and the climatic variables. The Monte Carlo simulation generates random data matrices to prove the presence/absence of the effects of the variables.

\section{Results}

During the collection period from October 2015 to December 2016, a total of 7186 eggs were collected and 1206 specimens of Culicidae were identified, representing three genera and five species: H. (Conopostegus) leucocelaenus Dyar \& Shannon, 1924: 992 specimens; H. (Haemagogus) janthinomys Dyar, 1921: 63 specimens; Aedes (Stegomyia) albopictus Skuse, 1894: 103 specimens; Aedes (Stegomyia) aegypti Linnaeus, 1752: 42 specimens; Culex (Carrollia) iridescens Lutz, 1905: 4 specimens; and Limatus durhamii Theobald, 1901: 2 specimens (Table 1).

Monthly variation-maximum abundance of $H$. leucocelaenus, was observed in December 2015 and November 2016, whereas $H$. janthinomys was more frequent in February and November 2016. A. albopictus was found most frequently in October and November 2015, whereas A. aegypti and $C$. iridescens were more abundant in October 2015 and November 2015, respectively (Table 2).

The climatic variables that were significantly correlated with mosquito densities were precipitation $(p=0.0080)$, maximum dew point $(p=0.0348)$, and direction $(p=0.0346)$. $H$. janthinomys individuals were positively correlated with the three climatic variables, whereas, H. leucocelaenus individuals showed positive correlation with precipitation and maximum dew point, and were negatively correlated with direction (Fig. 2).

Based on the number of the collected mosquito eggs, the results revealed a high level of population density of vectors in summer and spring, comprising 2002 and 1102 eggs in February and November 2016 (Table 3). A simple linear regression was performed using the software R, version 3.4.1, with a confidence index of $95 \%$ and $p<0.05$ to analyze the 
Table 1. The Percentage and Number of Species Collected from Each of the Collection Points Located in Bom Retiro Private Natural Reserve, State of Rio de Janeiro, Brazil, FROM OCTOBER 2015 TO OCTOBER 2016

\begin{tabular}{lrrrrrrrr}
\hline Species & Site 1 & Site 2 & Site 3 & Site 4A & Site 4 B & Site 5 & Total & $\%$ \\
\hline Haemagogus janthinomys & 0 & 0 & 0 & 1 & 5 & 57 & 63 & 5.22 \\
Haemagogus leucocelaenus & 2 & 0 & 0 & 137 & 633 & 220 & 992 & 82.26 \\
Aedes albopictus & 44 & 55 & 3 & 0 & 1 & 0 & 103 & 8.54 \\
Aedes aegypti & 0 & 0 & 0 & 0 & 42 & 0 & 42 & 3.48 \\
Culex iridescens & 0 & 0 & 0 & 0 & 4 & 0 & 4 & 0.33 \\
Limatus durhamii & 0 & 0 & 0 & 2 & 0 & 0 & 2 & 0.17 \\
Total & 46 & 55 & 3 & 140 & 685 & 277 & 1206 & 100
\end{tabular}

correlation between the number of eggs and rainfall, using the number of eggs as the discrete variable and rainfall as the continuous variable (Table 4). The regression analysis revealed that the number of mosquito eggs was significantly associated with rainfall ( $p=0.003561$ ) (Fig. 3).

To understand the similarities and differences between the sampling units, a nonmetric multidimensional scale was used to represent the original position of the mosquito communities in the multidimensional space as accurately as possible using a small number of dimensions that can be easily plotted and visualized. Figure 4 shows the level of similarity and differences among the sampling points of collection based on their proximity to each other. Coordinates 1 and 2 assist in the allocation of these points in a Cartesian plane.

Table 2. Relative Abundance and Percentage of Mosquito Species Collected Using Oviposition Traps at the Bom Retiro Private Natural Reserve, State of Rio de Janeiro, Brazil, FROM OCTOBER 2015 TO OCTOBER 2016

RPPNBR/No. of species per month

\begin{tabular}{|c|c|c|c|c|c|c|c|}
\hline $\begin{array}{l}\text { Species } \\
\text { Period }\end{array}$ & A. albopictus & A. aegypti & H. leucocelaenus & $\mathrm{H}$ janthinomys & C. iridescens & Limatus durhamii & Total \\
\hline \multicolumn{8}{|l|}{2015} \\
\hline October & 42 & 42 & 67 & 4 & 0 & 0 & 155 \\
\hline$\%$ & 3.48 & 3.48 & 5.56 & 0.33 & 0.00 & 0.00 & 10.55 \\
\hline November & 54 & 0 & 82 & 2 & 4 & 0 & 142 \\
\hline$\%$ & 4.48 & 0.00 & 6.80 & 0.17 & 0.33 & 0 & 11.77 \\
\hline December & 6 & 0 & 219 & 2 & 0 & 0 & 227 \\
\hline$\%$ & 0.50 & 0.00 & 18.16 & 0.17 & 0.00 & 0.00 & 18.82 \\
\hline \multicolumn{8}{|l|}{2016} \\
\hline February & 0 & 0 & 132 & 41 & 0 & 0 & 173 \\
\hline$\%$ & 0.00 & 0.00 & 10.95 & 3.40 & 0.00 & 0.00 & 14.34 \\
\hline March & 0 & 0 & 14 & 0 & 0 & 0 & 15 \\
\hline$\%$ & 0.00 & 0.00 & 1.16 & 0.00 & 0.00 & 0.00 & 1.24 \\
\hline April & 9 & 0 & 22 & 0 & 0 & 0 & 31 \\
\hline$\%$ & 0.75 & 0.00 & 1.82 & 0.00 & 0.00 & 0.00 & 2.57 \\
\hline May & 0 & 0 & 0 & 0 & 0 & 0 & 0 \\
\hline$\%$ & 0 & 0 & 0 & 0.00 & 0.00 & 0.00 & 0.00 \\
\hline June & 19 & 0 & 0 & 0 & 0 & 0 & 19 \\
\hline$\%$ & 1.58 & 0.00 & 0.00 & 0.00 & 0.00 & 0.00 & 1.58 \\
\hline July & 0 & 0 & 0 & 0 & 0 & 0 & 0 \\
\hline$\%$ & 0 & 0 & 0 & 0 & 0 & 0 & 0 \\
\hline August & 0 & 0 & 9 & 0 & 0 & 0 & 9 \\
\hline$\%$ & 0.00 & 0.00 & 0.75 & 0.00 & 0.00 & 0.00 & 0.75 \\
\hline September & 0 & 0 & 26 & 1 & 0 & 0 & 26 \\
\hline$\%$ & 0.00 & 0.00 & 2.16 & 0.08 & 0.00 & 0.00 & 2.16 \\
\hline October & 0 & 0 & 31 & 1 & 0 & 0 & 31 \\
\hline$\%$ & 0.00 & 0.00 & 2.57 & 0.08 & 0.00 & 0.00 & 2.57 \\
\hline November & 25 & 0 & 333 & 18 & 0 & 0 & 376 \\
\hline$\%$ & 2.07 & 0.00 & 27.61 & 1.49 & 0.00 & 0.00 & 31.18 \\
\hline December & 0 & 0 & 0 & 0 & 0 & 0 & 0 \\
\hline$\%$ & 0.00 & 0.00 & 0.00 & 0.00 & 0.00 & 0.00 & 0.00 \\
\hline Total & 155 & 42 & 935 & 70 & 4 & 0 & 1206 \\
\hline$\%$ & 1.85 & 3.48 & 77.53 & 5.80 & 0.33 & 0.00 & 100.00 \\
\hline
\end{tabular}

RPPNBR, Bom Retiro Private Natural Reserve. 


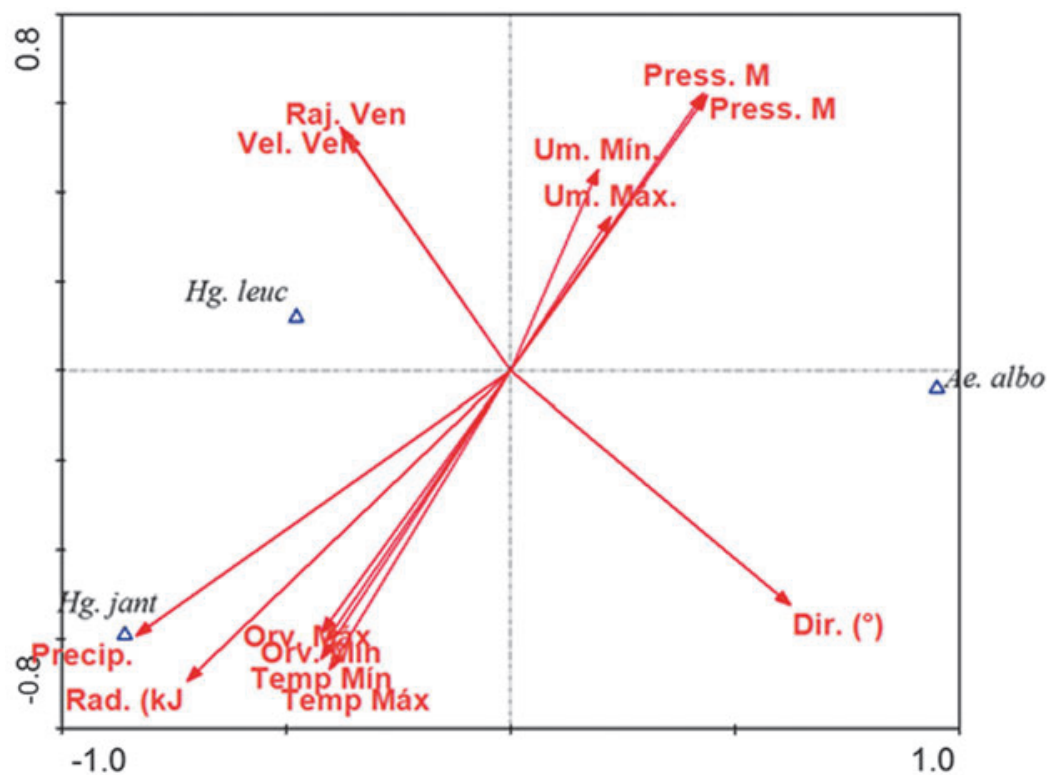

FIG. 2. Direction and proximity of the climatic variables. The red vectors indicate the direction and proximity of the climatic variables in relation to each species studied. The greater the proximity of these vectors with the species (in blue triangle representative of the respective populations), the stronger the interaction between the two. Dir. $\left(^{\circ}\right)$ (Direction), Orv. Max (Maximum dew point), Orv. Min (Minimum dew point), Temp Min (Minimum temperature), Temp Max (Maximum temperature), Precip. (Precipitation or Rainfall), Rad. (Radiation), Raj. Ven. (Wind Gust), Vel. Ven. (Wind speed), Press. M (Maximum pressure), Press Min. (Minimum pressure), Um. Mín. (Minimum humidity), Um. Max (Maximum humidity).
The most distinct collection sites observed were $4 \mathrm{~A}$ and $4 \mathrm{~B}$ and most similar were 1 and 2 . The sampling sites $4 \mathrm{~A}$ and 3 were similar in relation to coordinate 1 ; however, they were distinct from coordinate 2 . Sites 3 and $4 \mathrm{~B}$ were similar in relation to coordinate 2 ; however, they were very different from coordinate 1 (Fig. 4).

\section{Discussion}

Understanding the biodiversity of mosquito species in the Atlantic Forest is fundamental for the prediction of possible changes in their populations. The mosquito fauna present in this environment has great biodiversity, including potential vectors of the yellow fever virus and other arboviruses. Mosquitoes of the genera Haemagogus and Sabethes spp. are the main vectors of the wild-type yellow fever virus in the forest areas of the Americas, and are of major importance in the transmission of this arbovirus (Vasconcelos et al. 2003).

Table 3. Number of Hatched Eggs and Nonhatched EgGs, COLleCted FROM OCTOBER 2015 to November 2016 at the Bom Retiro Private Natural Reserve, State of Rio de Janeiro, Brazil

\begin{tabular}{lccr}
\hline Months/years & Hatched eggs & Nonhatched eggs & Total \\
\hline October/2015 & 36 & 408 & 444 \\
November/2015 & 73 & 492 & 565 \\
December/2015 & 105 & 998 & 1103 \\
February/2016 & 818 & 1184 & 2002 \\
March/2016 & 14 & 43 & 57 \\
April/2016 & 81 & 281 & 362 \\
May/2016 & 0 & 1 & 1 \\
June/2016 & 0 & 21 & 21 \\
July/2016 & 69 & 42 & 111 \\
August/2016 & 168 & 283 & 451 \\
September/2016 & 280 & 268 & 548 \\
October/2016 & 117 & 302 & 419 \\
November/2016 & 238 & 864 & 1102 \\
Total & 1999 & 5187 & 7186 \\
\hline
\end{tabular}

Most of the species found in this study are known to be vectors of several agents considered pathogenic to humans. $H$. janthinomys stands out as the main vector of the wild-type yellow fever virus in the Americas, as well as being a vector of other arboviruses, such as Mayaro and Ilheus (Vasconcelos et al. 2003). H. leucocelaenus is a vector of wild-type yellow fever virus in Brazil (Arnell 1973). A. aegypti and A. albopictus are known vectors of dengue virus (WHO 2017). A. aegypti is also known to transmit other viral diseases, such as yellow fever, chikungunya (Powell and Tabachnick 2013), and Zika (Marchette et al. 1969, Diallo et al. 2014). Culex can transmit pathogens responsible for causing encephalitis, lymphatic filariasis, and heartworm disease (Service 1993).

Alencar et al. (2015) conducted a study in the Guapiaçu Ecological Reserve, Rio de Janeiro, Brazil, and found that the largest number of specimens was observed in April and December. Similarly in this study, a peak was observed in the number of A. albopictus and H. leucocelaenus in April and December. The highest number of individuals of $H$. janthinomys was observed in February 2016. This result is similar

Table 4. Number of Eggs Collected at the Bom Retiro Private Natural Reserve, State

of Rio de Janeiro, From February to October 2016, AND RAINFALl IN MM ACCORDING TO THE DATA From the National Institute of Meteorology

\begin{tabular}{lrc}
\hline Months/years & Eggs & Rainfall $(\mathrm{mm})$ \\
\hline February/2016 & 2002 & 0.56 \\
March/2016 & 57 & 0.29 \\
April/2016 & 362 & 0.06 \\
May/2016 & 1 & 0.06 \\
June/2016 & 21 & 0.07 \\
July/2016 & 111 & 0.01 \\
August/2016 & 451 & 0.02 \\
September/2016 & 548 & 0.07 \\
October/2016 & 419 & 0.11 \\
November/2016 & 1102 & 0.39
\end{tabular}




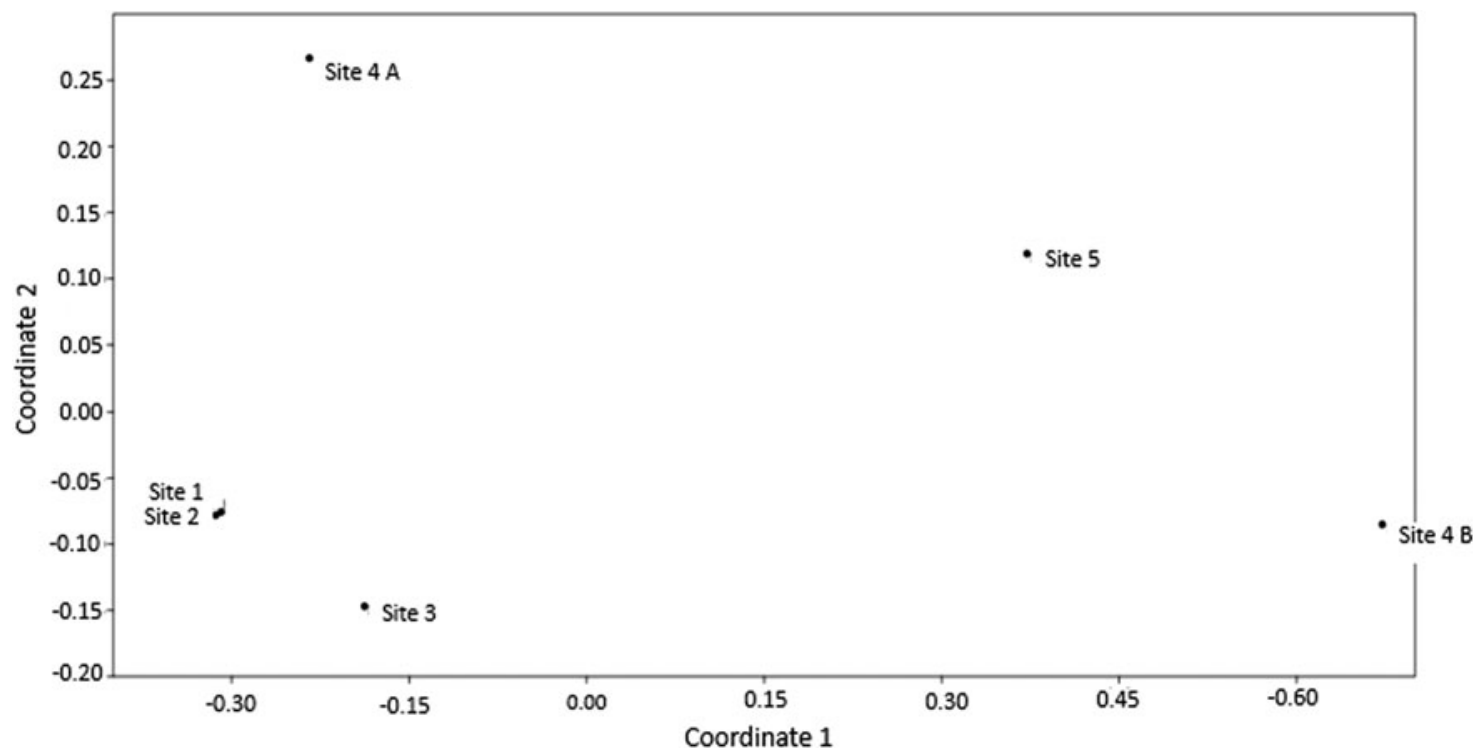

FIG. 3. Assessment of the significant differences among the collected sites (Site 1, Site 2, Site 3, Site 4 A, Site 4 B, and Site 5).

to that obtained by Pinto et al. (2009) in a study conducted in the National Forest of Caxiuanã, Pará, Brazil, who reported an increased abundance of $H$. janthinomys in the same month.

In this study, $H$. leucocelaenus showed a positive correlation with precipitation and maximum dew point, indicating an influence of these abiotic factors on its behavior and subsequent increase in its population. Similar results were reported by Resende et al. (2013) who reported a positive and significant correlation between rainfall and monthly frequency of $H$. leucocelaenus.

Alencar et al. (2011) reported that the populations of $H$. janthinomys analyzed were significantly influenced by rainfall, leading to a change in the activity rhythm, thereby increasing the population density in the rainy seasons. This study also showed that $H$. janthinomys individuals were favored by the three climatic variables: precipitation, maximum dew point, and direction.

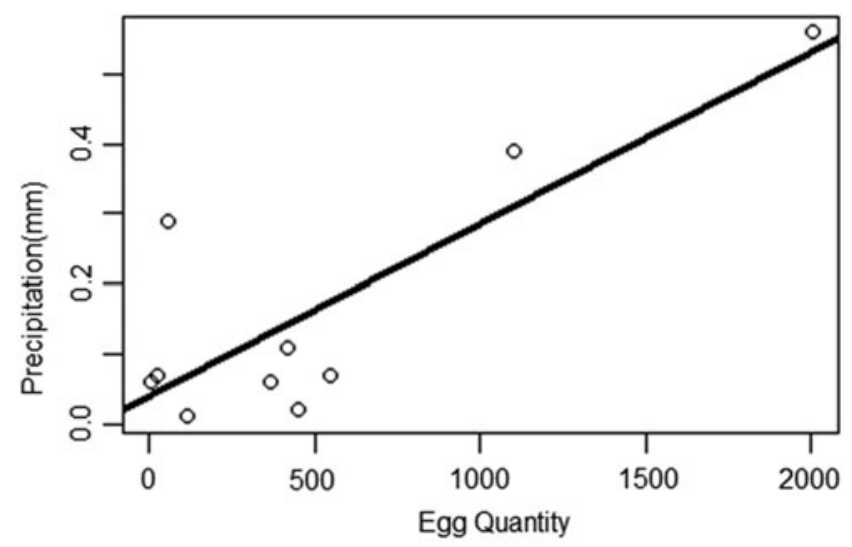

FIG. 4. Number of eggs collected at RPPNBR, state of Rio de Janeiro, Brazil, from February to October 2016, and rainfall in $\mathrm{mm}$ (INMET). INMET, National Institute of Meteorology.
Marteis et al. (2017) found that a high relative air humidity index guaranteed the maintenance of natural breeding sites in the wild environments and promoted the formation of larval habitats, consequently influencing the population density of adults. These observations are in agreement with the results of this study, considering that both H. leucocelaenus and $H$. janthinomys species were positively correlated with maximum dew point. Patz et al. (2003) reported that the increase in rainfall influences the breeding behavior of the vectors, consequently favoring population growth. The same trend was also observed in both $H$. leucocelaenus and $H$. janthinomys species that had a positive correlation with precipitation in this study.

Furthermore, the fact that many human communities in different Brazilian regions do extensive work and/or leisure activities in the nocturnal twilight period is worthy of special attention. These activities increase the chances of their encounter with the vectors of yellow fever virus. In addition, such activities can also increase the confirmed yellow fever cases in nonhuman primates in the region surrounding the RPPNBR, which highlights the importance for conducting entomological surveillance in this area.

\section{Conclusions}

Knowledge regarding the distribution of vector species is crucial for the improvement and maintenance of operations that promote the surveillance and control of these arthropods and with evidence of active sylvatic yellow fever virus transmission next to the natural reserve studied here, the abundance of the mosquito vector for this disease in Brazil requires active surveillance on the emergence of the virus in neighboring communities (Forshey et al. 2010).

\section{Acknowledgments}

This work was supported by the Research Support Foundation of the State of Rio de Janeiro (FAPERJ, grant numbers 26/010.001630/2014, E-26/202.819/2015). We are thankful 
for comments and suggestions from anonymous reviewers that helped improve an earlier version of this article.

\section{Author Disclosure Statement}

No competing financial interests exist.

\section{References}

Alencar J, Fereira ZM, Lopes CM, Serra-Freire NM, et al. Biodiversity and times of activity of mosquitoes (Diptera: Culicidae) in the Biome of the Atlantic Forest in the State of Rio de Janeiro, Brazil. J Med Entomol 2011; 48:223-231.

Alencar J, de Mello CF, Gil-Santana HR, Guimarães AE, et al. Vertical oviposition of mosquitoes in the Atlantic Forest of Brazil with emphasis on the sylvan vector, Haemagogus leucocelaenus (Diptera: Culicidae). J Vector Ecol 2016; 41:18-26.

Alencar J, Mello CF, Guimarães AE, Gil-Santana HR, et al. Temporal dynamics in Guapiaçu Ecological Reserve, Cachoeiras de Macacu, Rio de Janeiro, Brazil. PLos One 2015; 10:e0122268.

Alencar JA, Gil-Santana HR, Lopes CM, Santos JS, et al. Use of an 'ovitrampa' trap for monitoring Haemagogus janthinomys (Diptera: Culicidae) in the Atlantic Forest area. Entomol Vec 2004; 11:369-374.

Arnell JH. Mosquito Studies (Diptera, Culicidae) XXXII. A Revision of the Genus Haemagogus. Los Angeles: California Press, 1973:1-174.

Braga IA, Valle D. Aedes aegypti: History of control in Brazil. Health Service 2007; 16:113-118.

Braks MAH, Nonório, NA, Lounibos, LP, Lourenço-de-Olveira, $\mathrm{R}$, et al. Interespecific competition between tow invasive species of container mosquitões, Aedes aegypti and Aedes albopictus (Diptera: Culicidae) in Brazil. Ann Entomol Soc Am 2004; 97 : 130-139.

Chadee DD, Tikasingh WI. Observations on the Seasonal Incidence and Diel Oviposition periodicicity of Haemagogus mosquitoes (Diptera: Culicidae) in Trindad. Ann Trop Med Parasitol 1990; 84:267-275.

Chaves LF, Koenraadt CJM. Climate change and highland malaria: Fresh air for a hot debate. Q Rev Biol 2010; 85:27-55.

Clima-data.org. Clima Casimiro de Abreu. Available at https:// pt.climate-data.org/location/33703

Consoli RAGB, Oliveira, RL. Principais Mosquitos de Importância Sanitária no Brasil. Rio de Janeiro: Editora FIOCRUZ 1994:1-228.

Correa FF, Gleiser RM, Leite PJ, Fagundes E, et al. Mosquito (Diptera: Culicidae) communities in Nova Iguaçu Natural Park Rio de Janeiro, Brazil. J Am Mosquito Control Assoc 2014; 30:83-90.

Cunha SB. Engineering Works Impacts on the Biophysical Environment of the São João River Basin (Rio de Janeiro, Brazil). Rio de Janeiro: Author Editing, 1995:1-415

Diallo D, Sall AA, Diagne CT, Faye O, et al. Zika virus emergence in mosquitoes in southeastern Senegal, 2011. PLoS One 2014; 9:e109442.

Dobson AP. Population dynamics of pathogens with multiple host species. Am Nat 2004; 164:S64-S78.

Forattini OP. Culicidologia Médica, vol. 2. São Paulo: Faculdade de Saúde Pública, Universidade de São Paulo, 2002:1-860.

Forshey BM, Guevara C, Laguna-Torres VA, et al. Arboviral etiologies of acute febrile illnesses in western South America, 2000-2007. PLoS Negl Trop Dis 2010; 4:e787.

Gilbert L, Norman R, Laurenson K, Reid, HW, et al. Disease persistence and apparent competition in a threehost commu- nity: An empirical and analytical study of largescale, wild populations. J Anim Ecol 2001; 70:1053-1061.

Glasser CM, Gomes AC. Infestation of the state of. By Aedes aegypti and Aedes albopictus. Public Health Journal 2000; 34:570-577.

Gomes AC. Measures of Urban Infestation Levels for Aedes (Stegomyia) aegypti and Aedes (Stegomyia) albopictus in an Entomological Monitoring Program. IESUS VII 1998: 50-57.

Hardy JL, Monath TP. Susceptibility and Resistence of Vector Mosquitoes. The Arboviruses: Epidemiology and Ecology. Boca Raton, FL: CRC Press, 1988:87-126.

Holt RD, Pickering J. Infectious disease and species coexistence: A model of Lotka-Volterra form. Am Nat 1985; 126: 196-211.

Hughes L. Biological consequences of global worming: Is the signal already apparent? Trends Eco Evol 2000; 15: 56-61.

Johnson PTJ, Thieltges DWJ. Community diversity reduces Schistosoma mansoni transmission, host pathology and human infection risk. Exp Biol 2010; 213:961-997.

Juliano SA. Species introduction and replacement amount mosquitoes: Interspecific resource competition or apparent competition? Ecology 1998; 79:255-268.

Keesing F, Holt RD, Ostfeld RS. Effects of species diversity on disease risk. Ecol Lett 2006; 9:485-498.

Marchette NJ, Garcia R, Rudnick A. Isolation of Zika virus from Aedes aegypti mosquitoes in Malaysia. Am J Trop Med Hyg 1969; 18:411-415.

Marcondes CB, Alencar J. Revision of mosquitoes Haemagogus Williston (Diptera: Culicidae) from Brazil. Rev Biomed 2010; 21:221-238.

Marques TC, et al. Mosquito (Diptera: Culicidae) assemblages associated with Nidularium and Vriesea bromeliads in Serra do Mar, Atlantic Forest, Brazil. Parasit Vectors 2012; 5:41.

Marteis LS, Natal D, Sallum MAM, Medeiros-Sousa AR, et al. Mosquitoes of the Caatinga: 1. Adults stage survey and the emerge of seven New species endemic of a dry tropical forest in Brazil. Elsevier 2017; 166:193-201.

Medeiros AS. Dípteros (Culicidae) Transmissores de Arbovírus em Área de Proteção Ambiental Urbana (Parque Estadual das Dunas Natal-RN) 2004-2006. Dissertação de Mestrado (Mestrado em Ciências da Saúde)-Universidade Federal do Rio Grande do Norte, 2009:110.

Norman R, Bowers RG, Begon, M, Hudson, PJ. Persistence of tick-borne virus in the presence of multiple host species: Tick reservoirs and parasite-mediated competition. J Theor Biol 1999; 200:111-118.

Passos RA, Marques GRAM, Voltolini JC, Condino LF. Aedes aegypti dominance on Aedes albopictus on the southeast coast of Brazil. Public Health Journal. 2003; 37:729-734.

Patz JA, McMichael DH, Campbell-Lendrum CF, et al. Climate Change and Human Health. Risk and Responses. WHO, Geneva: World Health Organization, 2003:103-132.

Pinto CS, Confaloieri UEC, Mascarenhas BM. Ecology of Haemagogus sp. and Sabethes sp. (Diptera: Culicidae) in relation to the microclimates of the Caxiuanã National Forest, Pará, Brasil. Mem Inst Oswaldo Cruz 2009; 104:592-598.

Powell JR, Tabachnick WJ. History of Domestication and Spread of Aedes aegypti-A Review, vol. 1. Rio de Janeiro, Brazil: Mem Inst Oswaldo Cruz Academic Press, 2013:11-17.

Reinert JF. Revised list of abbreviations for genera and subgenera of Culicidae (Diptera) and notes on generic and subgeneric changes. J Am Mosq Control Assoc 2001; 17:51-55. 
Resende MC, Silva IM, Ellis BR, Eiras AE. A Comparasion of Larval Ovitrap and MosquitoTRAP Surveillance for Aedes (Stegomyia) aegypti, vol. 108. Rio de Janeiro, Brazil: Mem Inst Oswaldo Cruz Academic Press, 2013: 1024-1030.

Saul A. Zooprophylaxis or zoopotentiation: The outcome of introducing animals on vector transmission is highly dependent on the mosquito mortality while searching. Malar J 2003; 2: 32-50.

Schmidt KA, Ostfeld, RS. Biodiversity and the dilution effect in disease ecology. Ecology 2001; 82:609-619.

Schobbenhaus C, Campos DA, Derze GR, Asmus, HE, et al. Geological map of Brazil and the adjacent ocean area including mineral deposits. 1995. [cited December 15, 2017]; Available at http://rigeo.cprm.gov.br/jspui/handle/doc/8516

Service MW. Mosquito Ecology: Field Sampling Method. London: Applied Science Publ, 1993.

Takizawa FH. Pedological Survey and Environmental Zoning of the Biological Reserve of Poço das Antas. Piracicaba, Department of Soil Science, Luiz de Queiroz College of Agriculture, University of Sao Paulo 1995: 1-176.
Ter braak CJF, Smilauer P. CANOCO Reference Manual and CanoDraw for Windows User's Guide: Software for Canonical Community Ordination (version 4.5). Ithaca, Microcomputer Power, 2002;500p.

Vasconcelos PF, Sperb AF, Monteiro HA, Torres MA, et al. Isolations of yellow fever virus from Haemagogus leucocelaenus in Rio Grande do Sul State, Brazil. Trans R Soc Trop Med Hyg 2003; 97:60-62.

WHO. Dengue and severe dengue. 2017. Available at www .who.int/mediacentre/factsheets/fs117/en

Address correspondence to: Jeronimo Alencar Diptera Laboratory

Oswaldo Cruz Institute (Fiocruz) Avenida Brasil 4365

Rio de Janeiro 21040-360

Brazil

E-mail: jalencar@ioc.fiocruz.br 